\title{
[DL-1,2-Bis(2-hydroxyphenyl)ethylenediamine]dichloroplatinum(II), a new compound for the therapy of ovarian cancer
}

\author{
Richard Müller ${ }^{1}$, Ronald Gust ${ }^{1}$, Günther Bernhardt ${ }^{1}$, Christoph Keller ${ }^{1}$, Helmut Schönenberger ${ }^{1}$, \\ Siegfried Seeber ${ }^{2}$, Reinhardt Osieka ${ }^{3}$, Alan Eastman ${ }^{4}$, and Margaretha Jennerwein ${ }^{4}$ \\ ${ }^{1}$ Institut für Pharmazie, Lehrstuhl Pharmazeutische Chemie II, Sonderforschungsbereich 234, Universität Regensburg, \\ Universitätsstraße 31, D-8400 Regensburg, Federal Republic of Germany \\ ${ }^{2}$ Städtisches Krankenhaus Leverkusen, Zentrum Innere Medizin, Medizinische Klinik III, Dhünnberg 60, \\ D-5090 Leverkusen 1, Federal Republic of Germany \\ ${ }^{3}$ Medizinische Klinik IV der Medizinischen Fakultät der RWTH Aachen, Pauwelsstraße 30, D-5100 Aachen, Federal Republic of Germany \\ ${ }^{4}$ Dartmouth Medical School, Department of Pharmacology and Toxicology, Hanover, New Hampshire 03756, USA
}

Received 20 October 1989/Accepted 5 February 1990

Summary. The synthesis of diastereoisomeric [1,2-bis (2-hydroxyphenyl)ethylenediamine]dichloroplatinum(II) complexes, DL-3- $\mathrm{PtCl}_{2}$ and meso-3-PtCl 2 , and their evaluation on the hormone-independent, human MDAMB231 breast cancer cell line, on the cisplatin-sensitive and -resistant L1210 leukemia cell line, on the cisplatinresistant human NIH:OVCAR 3 ovarian cancer cell line, on the P-388 leukemia of the mouse and on the cisplatinsensitive and -resistant Ehrlich ascites tumor of the mouse are described. On all tumor models DL-3- $\mathrm{PtCl}_{2}$ produces a marked inhibitory effect. The diastereoisomer meso-3- $\mathrm{PtCl}_{2}$ is less active and more toxic. It is striking that $\mathrm{DL}-3-\mathrm{PtCl}_{2}$ leads to a pronounced inhibition of all cisplatin-resistant tumors. At non-toxic concentrations DL-3- $\mathrm{PtCl}_{2}$ produces cytocidal effects on the NIH:OVCAR 3 cell line. Therefore DL-3-PtCl ${ }_{2}$ is of interest for further evaluation for the therapy of ovarian cancer.

Key words: [DL-1,2-Bis(2-hydroxyphenyl)ethylenediamine]dichloroplatinum(II) - Ovarian cancer

\section{Introduction}

The first communication on the capability of cisplatin to initiate regression in advanced ovarian cancer was made by Wiltshaw and Carr (1974; see also Barker 1983). Cisplatin produces a therapeutic response even in patients with refractory ovarian carcinoma (Wiltshaw and Kroner 1976). In high dosage cisplatin leads to response rates up to $63 \%$ and in some cases to complete remissions $(18 \%)$ with a survival time greater than 2 years in several of these patients (Barker and Pring 1981; compare Ozols et al. 1985; Ozols and Young 1985; Eisenhauer et al. 1986).

The reason for the short overall survival time is the rapid development of resistance in ovarian tumor cells (Ozols and Young 1984, compare also Bruntsch 1985;

Offprint requests to: $\mathrm{H}$. Schönenberger
Weiss 1986). Cisplatin-resistant tumor cells show multiple biochemical differences in comparison to the related sensitive cells, e.g. a reduced capability to accumulate cisplatin, an increased intracellular level of glutathione and an enhanced DNA repair, i.e. cisplatin-nucleoside-adduct removal (see Lai et al. 1988 for references).

The Sonderforschungsbereich 234 has been working for some time on the development of platinum complexes that show an activity on cisplatin-resistant tumor models. Such compounds are of interest: (a) in combination with cisplatin for first-line treatment of ovarian cancer to avoid or retard the development of resistance; (b) for the second-line therapy of ovarian cancer after development of resistance against cisplatin.

In recent publications (Wappes et al. 1984; Jennerwein et al. $1989 \mathrm{a}, \mathrm{b}$ ) we have shown that stereoisomeric dichloro(1,2-diphenylethylenediamine)platinum(II) complexes with hydroxy groups in the 3 or 4 positions of both benzene rings (Scheme 1, compounds $1-\mathrm{PtCl}_{2}$ and $2-\mathrm{PtCl}_{2}$ ) possess a marked activity on the Ehrlich ascites tumor of the mouse. On the cisplatin-resistant variant of this tumor, however, only the 3-hydroxy derivatives (2$\mathrm{PtCl}_{2}$ ) lead to an inhibition of tumor growth (Jennerwein et al. $1989 \mathrm{~b}$ ). Their effect was most outstanding in the case of the compound with $R, R / S, S$ configuration ${ }^{1}$, which produced $40 \%$ cures at a dose of $3 \times 2.5 \mathrm{mg} / \mathrm{kg}$, i.p.

${ }^{1} R, R / S, S=$ racemate $=\mathrm{DL} ; R, S=$ meso

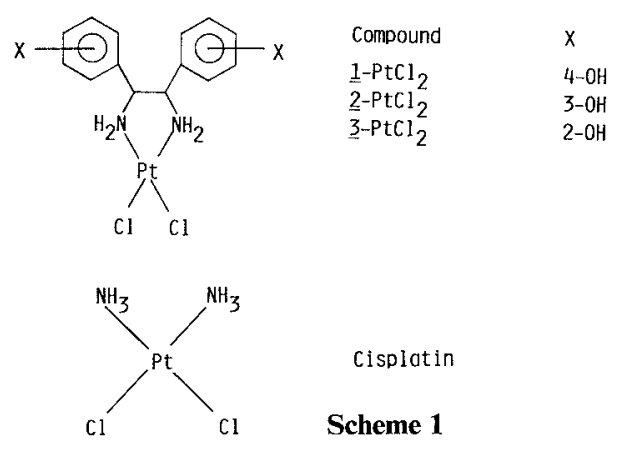


(days 1-3). The combination of compound $2-\mathrm{PtCl}_{2}(S, S$ configuration) with cisplatin results in a weakly synergistic effect in cell culture experiments using the hormoneindependent human MDA-MB231 breast cancer cell line (Jennerwein et al. 1989 b).

To our surprise, the shift of both $\mathrm{OH}$ groups of the $R, R / S, S$ compound $2-\mathrm{PtCl}_{2}$ from the 3 into the 2 position (compound DL-3- $\mathrm{PtCl}_{2}$ ) produces a distinct elevation of antitumor activity on the cisplatin-resistant Ehrlich ascites tumor (Scheme 1).

This publication will report on the synthesis of the two diastereoisomeric [1,2-bis(2-hydroxyphenyl)ethylenediamine]dichloroplatinum(II) compounds (DL-3$\mathrm{PtCl}_{2}$ and $m e s o-3-\mathrm{PtCl}_{2}$ ) and their antitumor activity on several tumor models.

\section{Materials and methods}

Chemistry. meso-1,2-Bis(2-hydroxyphenyl-ethylenediamine (meso3), originally described by Japp and Hooker (1884), was synthesized from salicylic aldehyde and ammonia using an improved method published by Vögtle and Goldschmitt (1976). $N, N^{\prime}$-Disalicylidenemeso-1,2-bis(2-methoxyphenyl)ethylenediamine (meso-3c) was synthesized by the stereospecific [3.3] sigmatropic diaza-Cope rearrangement reaction according to the method of Vögtle and Goldschmitt (1976) from meso-1,2-bis(2-hydroxyphenyl)ethylenediamine (meso-3) and 2-methoxybenzaldehyde in boiling $\mathrm{CH}_{3} \mathrm{CN}$ (Scheme 2, method A). Upon hydrolysis with $3 \mathrm{M} \mathrm{H}_{2} \mathrm{SO}_{4}$ meso-1,2bis(2-methoxyphenyl)ethylenediamine (meso-3a) was obtained (Scheme 2, method B). The reaction of meso-3a with 2-methoxybenzaldehyde led to the symmetrical diimine meso- $3 b$ (Scheme 2, method C). The compound meso- $3 b$ was melted. At temperatures higher than $120^{\circ} \mathrm{C}$ there is equilibrium between the diimines meso$3 b$ and $\mathrm{DL}-3 b$. The diastereoisomeric products were separated by their different solubility in $\mathrm{CH}_{2} \mathrm{Cl}_{2}$ (Scheme 2, method D). DL-1,2Bis(2-methoxyphenyl)ethylenediamine (DL-3a) was prepared by hydrolysis of DL- $3 b$ in $3 \mathrm{M} \mathrm{H}_{2} \mathrm{SO}_{4}$ (Scheme 2, method E). DL-1,2-Bis(2hydroxyphenyl)ethylenediamine (DL-3) was obtained by ether cleavage of DL-3a (Scheme 2, method F). It was difficult to find an appropriate method for this reaction. Various ether cleavages with $\mathrm{BBr}_{3} /$ $\mathrm{CH}_{2} \mathrm{Cl}_{2}$ abs., $\mathrm{HBr}$, $\mathrm{HI}$ and $\mathrm{BBr}_{3}$ /boiling $\mathrm{CHCl}_{3}$ abs. were tested, and the best results seemed to be achieved by using $\mathrm{BBr}_{3}$ in $\mathrm{CH}_{2} \mathrm{Cl}_{2}$ at room temperature for 3 days. Trials to purify DL- 3 further caused its decomposition and were avoided. [DL-1,2-Bis(2-hydroxyphenyl)ethylenediamine]dichloroplatinum(II) (DL-3-PtCl 2 ) was synthesized by reaction of DL-1,2-bis(2-hydroxyphenyl)ethylenediamine (DL-3) with $\mathrm{K}_{2} \mathrm{PtCl}_{4}$ (Scheme 3, method G). For steric reasons the complexation of meso ligands proceeds very slowly. Therefore faster complexation was achieved with the reaction of $\mathrm{K}_{2} \mathrm{PtI}_{4}$ and meso1,2-bis(2-hydroxyphenyl)ethylenediamine (meso-3) (Scheme 3, method $\mathrm{H}$ ). To exchange iodine for chlorine, $\mathrm{I}^{-}$was precipitated with $\mathrm{Ag}_{2} \mathrm{SO}_{4}$ and subsequently the intermediate di-aqua complex was converted to the dichloro complex $\left(\right.$ meso $-3-\mathrm{PtCl}_{2}$ ) by addition of $\mathrm{KCl}$ (Scheme 3, method I). The purity of the platinum compounds was confirmed by elemental analysis (Table 1) and HPLC (Table 4). The infrared and ${ }^{1} \mathrm{H}-\mathrm{NMR}$ data (Table 2) are in good agreement with former results. In the phenolic ligands (meso-3 and DL-3) the hydroxy and the amine protons appear as one signal (Table 2). After complexation the peaks for $\mathrm{OH}$ and $\mathrm{NH}_{2}$ are separated.

meso-N, $\mathrm{N}^{\prime}$-Disalicylidene-1,2-bis (2-methoxyphenyl)ethylenediamine (meso-3c) method A. meso-1,2-Bis(2-hydroxyphenyl)ethylenediamine (meso-3, 47,52 $\mathrm{g}=0.195 \mathrm{~mol}$ ) and 2-methoxybenzaldehyde $(52.97 \mathrm{~g}=0.389 \mathrm{~mol})$ are refluxed in $300 \mathrm{ml} \mathrm{MeCN}$ for $3 \mathrm{~h}$. The solution is concentrated to $150 \mathrm{ml}$. After standing in the refrigerator für $1 \mathrm{~h}$ the precipitate is collected in a Buchner funnel, washed with small amounts of ice-cold $\mathrm{MeCN}$ and dried over $\mathrm{P}_{2} \mathrm{O}_{5}$. Yield: $92 \%$; yellow powder, $\mathrm{mp}: 211^{\circ}-212^{\circ} \mathrm{C}$.

meso-1,2-Bis (2-methoxyphenyl)ethylenediamine (meso-3a) method B. Meso-3c $(77.52 \mathrm{~g}=0.161 \mathrm{~mol})$ is hydrolyzed with $700 \mathrm{ml}$ $3 \mathrm{M} \mathrm{H}_{2} \mathrm{SO}_{4}$ and the salicylic aldehyde formed is removed by steam distillation. The hot solution is filtered and made alkaline with $20 \%$ $\mathrm{NaOH}$ under vigorous stirring and cooling by ice. The diamine is extracted with $\mathrm{CH}_{2} \mathrm{Cl}_{2}$ and the organic phase is dried over $\mathrm{MgSO}_{4}$. The solvent is removed under reduced pressure and the residue is dried over $\mathrm{P}_{2} \mathrm{O}_{5}$. Yield: $89 \%$; colorless solid, mp: $75^{\circ}-76^{\circ} \mathrm{C}$.

meso-N, $\mathrm{N}^{\prime}$-Bis (2-methoxybenzylidene)-1,2-bis(2-methoxyphenyl)ethylenediamine (meso-3b) method $C$. meso- $3 a \quad(37.36 \mathrm{~g}=$ $0.137 \mathrm{~mol}$ ) is treated as described in method A. Yield: $81 \%$; colorless powder, mp: $215^{\circ}-217^{\circ} \mathrm{C}$.

DL-N,N'-Bis (2-methoxybenzylidene)-1,2-bis (2-methoxyphenyl)ethylenediamine (DL-3b) method D. meso- $3 b(56.38 \mathrm{~g}=0.111 \mathrm{~mol})$ is melted under vigorous stirring. After $10 \mathrm{~min}$ the liquid is allowed to cool. The glassy mass is stirred with $250 \mathrm{ml} \mathrm{CH}{ }_{2} \mathrm{Cl}_{2}$ for $16 \mathrm{~h}$. The precipitate $(=$ meso- $3 b)$ is collected in a Buchner funnel and the solvent is removed from the filtrate under vacuum. The residue (DL- $3 b$ ) is dried over $\mathrm{P}_{2} \mathrm{O}_{5}$. Yield: $51 \%$ meso-3b, 44\% DL-3b; yellow powder, mp: $165-168^{\circ} \mathrm{C}$.

DL-1.2-Bis (2-methoxyphenyl)ethylenediamine (DL-3a) method E. DL- $3 b$ is hydrolyzed in the same manner as described in method B. Yield: $90 \%$; brown oil.
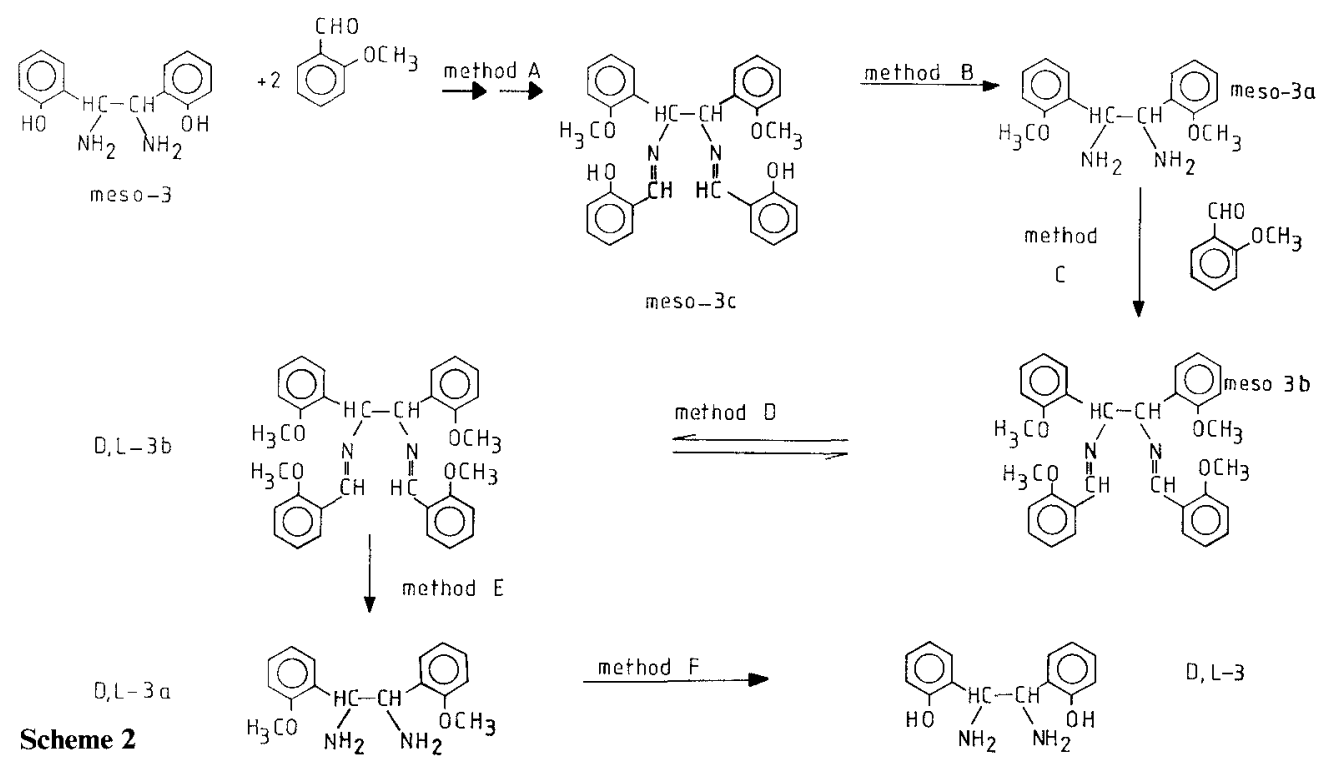

Scheme 2

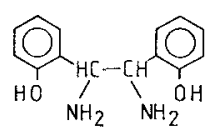




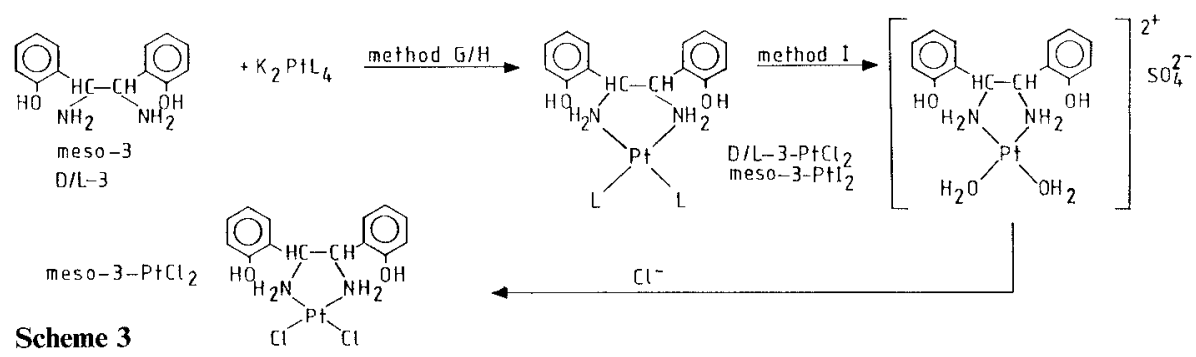

DL-1,2-Bis (2-hydroxyphenyl) ethylenediamine DL-3) method F. A solution of DL- $3 a(3.00 \mathrm{~g}=11.02 \mathrm{mmol})$ in $150 \mathrm{ml} \mathrm{CH} \mathrm{CH}_{2}$ abs. is cooled under stirring to $-60^{\circ} \mathrm{C} . \mathrm{BBr}_{3}(11.04 \mathrm{~g}=44.07 \mathrm{mmol})$ is added slowly with a syringe. The reaction mixture is stirred for $30 \mathrm{~min}$ at $-60^{\circ} \mathrm{C}$ and for 3 further days at room temperature, then $50 \mathrm{ml} \mathrm{CH}{ }_{3} \mathrm{OH}$ are added slowly under cooling and the solvent is removed under reduced pressure at $30^{\circ} \mathrm{C}$. This procedure is repeated twice. The residue is dissolved in $50 \mathrm{ml} \mathrm{H}_{2} \mathrm{O}$. The solution is filtered through a no. 3 fritted glass filter. The product is precipitated from the filtrate with $20 \% \mathrm{NaOH}$ at $\mathrm{pH} 9-11$ under cooling. The reaction mixture is extracted with ethyl acetate. The organic layer is dried over $\mathrm{MgSO}_{4}$. After filtration the organic layer is removed under reduced pressure at $30^{\circ} \mathrm{C}$ and the residue is dried over $\mathrm{P}_{2} \mathrm{O}_{5}$. Yield: $75 \%$; orange glassy mass.

[DL-1,2-Bis (2-hydroxyphenyl)ethylenediamine ] dichloroplatinum(II) DL-3- $\mathrm{PtCl}_{2}$ ) method $\mathrm{G}$. An aqueous solution of $\mathrm{K}_{2} \mathrm{PtCl}_{4}$ $(322 \mathrm{mg}=0.78 \mathrm{mmol}$ in $10 \mathrm{ml})$ is added slowly to a solution of DL-3 (190 $\mathrm{mg}=0.78 \mathrm{mmol}$ in $10 \mathrm{ml} \mathrm{H}_{2} \mathrm{O}$ and $2 \mathrm{ml} 2 \mathrm{M} \mathrm{HCl}$ ). The mixture is stirred in the dark at room temperature. The $\mathrm{pH}$ is kept at 2.5-3.5 for 2 days and at 5.5-6.5 for 3 further days. The complex is collected in a no. 3 fritted glass filter and washed three times with $1 \mathrm{M} \mathrm{HCl}$, and three times with water and dried under vacuum over silica gel $/ \mathrm{CaCl}_{2}$ at $80^{\circ} \mathrm{C}$. Yield: $78 \%$; yellow powder.

[meso-1,2-Bis (2-hydroxyphenyl)ethylenediamine] diiodoplatinum(II) (meso-3-PtI $)_{2}$ method $\mathrm{H}$. An aqueous solution of $\mathrm{K}_{2} \mathrm{PtCl}_{4}$ $(1.7 \mathrm{~g}=4.09 \mathrm{mmol}$ in $40 \mathrm{ml}$ water $)$ and $\mathrm{KI}[13.61 \mathrm{~g}=82 \mathrm{mmol})$ is stirred for $30 \mathrm{~min}$ at room temperature. meso-3 $(1.00 \mathrm{~g}=$ $4.09 \mathrm{mmol}$ ) is dissolved in $40 \mathrm{ml}$ water at $40^{\circ} \mathrm{C}$ by adding $2 \mathrm{M} \mathrm{HCl}$ dropwise. The dark $\mathrm{K}_{2} \mathrm{PtI}_{4}$ solution is added slowly to the ligand solution. The reaction mixture is stirred for $24 \mathrm{~h}$ at room temperature in the dark. The pH is kept between 5.5 and 6.5. The complex is collected in a no. 3 fritted glass filter and washed three times with $2 \mathrm{M}$ $\mathrm{HCl}$ and three times with water and dried under vacuum over silica $\mathrm{gel} / \mathrm{CaCl}_{2}$ at $80^{\circ} \mathrm{C}$. Yield: $67 \%$; yellow powder.

[meso-I,2-Bis (2-hydroxyphenyl) ethylenediamine] dichloroplatinum (II) (meso-3-PtCl 2$)$ method I. meso-3- $\mathrm{PtI}_{2}(504 \mathrm{mg}=0.73 \mathrm{mmol})$ and $\mathrm{Ag}_{2} \mathrm{SO}_{4}(227 \mathrm{mg}=0.79 \mathrm{mmol})$ are stirred for 5 days at room temperature in the dark. The precipitated $\mathrm{AgI}$ is filtered off with a no. 4 fritted glass filter. $\mathrm{KCl}(1.09 \mathrm{~g}=14.6 \mathrm{mmol})$ is added to the filtrate. After 1 day of stirring at room temperature the product is collected in a no. 3 fritted glass filter, washed three times with $1 \mathrm{M}$ $\mathrm{HCl}$ and water and dried over silica gel/ $\mathrm{CaCl}_{2}$ at $80^{\circ} \mathrm{C}$. Yield: $35 \%$; yellow powder.

General procedures. Melting points (uncorrected) were determined on a Büchi 510 melting point apparatus; for ${ }^{1} \mathrm{H}-\mathrm{NMR}$ spectra of the ligands a Varian EM $360-\mathrm{L}$ 60-MHz spectrometer was used and the ${ }^{1} \mathrm{H}-\mathrm{NMR}$ spectra of the platinum complexes were received on a Bruker PFR-NMR spectrometer WM 250 at $250 \mathrm{MHz}$. Elemental analyses were performed by the microlaboratory of the University of Regensburg. For the HPLC (Altex model 420; pump: Altex model $110 \mathrm{~A} ; \mathrm{C}_{18}$-reversed phase column, Merck, Lichrosorb), $1 \mathrm{mg}$ platinum complex dissolved in $1 \mathrm{ml}$ methanol is eluted with the solvent system: $60 \%$ methanol (Merck Lichrosolv)/ $40 \%$ bidistilled water, and assayed at $276 \mathrm{~nm}$ (Uvikon $720 \mathrm{LC}$ spectrometer).

\section{Biological methods}

MDA-MB231 human breast cancer cell line. The MDA-MB231 cell line (Lippman et al. 1977) was kindly provided by Dr. M.E. Lippman, NCI, Bethesda, USA. Cells were grown in a humified incubator in $5 \% \mathrm{CO}_{2}$, at $37^{\circ} \mathrm{C}$. McCoy 5 a medium, supplemented with gentamicin $(40 \mu \mathrm{g} / \mathrm{ml}), 10 \%$ newborn calf serum, and $\mathrm{NaHCO}_{3}$ $(11 \mathrm{~g} / 51)$ was used as culture medium. The cells were harvested with trypsin/EDTA, diluted with medium containing $5 \%$ newborn calf serum, and syringed gently to prevent clumping. Approximately $2 \times 10^{4}$ cells in $2 \mathrm{ml}$ were plated in duplicate in 6-well dishes (Costar). Then 2 days later the medium was changed and the Pt complexes were added as freshly prepared 1000 -fold concentrated solutions in dimethylformamide, leading to a final solvent concentration of $0.1 \%$. The cells of control wells contained an equal volume of dimethylformamide. After an incubation time of 2 days, which complied with a triple duplication time, the cells were labeled with $1 \mu \mathrm{Ci}$ $\left[{ }^{3} \mathrm{H}\right]$ thymidine/well for $2 \mathrm{~h}$. Cells were washed with ice-cold phosphate-buffered saline (PBS) and harvested with PBS/EDTA buffer. After centrifugation, the cell pellet was resuspended in $1 \mathrm{ml} P B S$ and divided into two $0.5-\mathrm{ml}$ aliquots. One part was counted in a $\mathrm{ZI}$ Coulter counter, the other was sonicated. After addition of $4 \mathrm{ml}$ $10 \%$ trichloroacetic acid, the acid-insoluble fraction was collected on a $0.45-\mu \mathrm{m}$ filter (Metricel, Gelman) and counted, after addition of $10 \mathrm{ml}$ scintillation liquid (LS 8000 Beckman scintillation counter).

The $\left[{ }^{3} \mathrm{H}\right]$ thymidine was obtained from New England Nuclear, Dreieich, FRG, the newborn calf serum from Biochrom, Berlin, the McCoy 5a medium and the trypsin $(0.05 \%)$ /EDTA $(0.02 \%)$ solution from Boehringer, Mannheim, FRG, and the scintillation liquid Quickszint 212 from Zinsser, Frankfurt, FRG. The PBS contained $\mathrm{NaCl}(8 \mathrm{~g}), \mathrm{KCl}(0.2 \mathrm{~g}), \mathrm{Na}_{2} \mathrm{HPO}_{4} \cdot 2 \mathrm{H}_{2} \mathrm{O}(1 \mathrm{~g}), \mathrm{NaH}_{2} \mathrm{PO}_{4} \cdot \mathrm{H}_{2} \mathrm{O}$ $(0.15 \mathrm{~g})$, and $\mathrm{KH}_{2} \mathrm{PO}_{4}(0.2 \mathrm{~g})$ in $11 \mathrm{H}_{2} \mathrm{O}$. To prepare PBS/EDTA buffer $0.02 \%$ EDTA was added to the PBS.

NIH:OVCAR-3 ovarian cancer cell line. The NIH:OVCAR-3 (ATCC no. HTB 161), a human adenocarcinoma of the ovary (Hamilton et al. 1983), was obtained from the American Type Culture Collection in passage 17. Cell-line banking and quality control were performed according to the "seed stock concept" reviewed by Hay (1988). The cells were maintained in RPMI-1640 (Sigma) containing $\mathrm{NaHCO}_{3}(2 \mathrm{~g} / 1)$, gentamicin $(50 \mathrm{mg} / \mathrm{l}), 10 \%$ BMS (Seromed) and insulin $(10 \mu \mathrm{g} / \mathrm{ml})\left(\right.$ Sigma) in $75-\mathrm{cm}^{2}$ flasks at $37^{\circ} \mathrm{C}$

Table 1. [1,2-Bis(2-hydroxyphenyl)ethylenediamine]dihaloplatinum(II) complexes: analytical data

\begin{tabular}{|c|c|c|c|c|c|c|}
\hline \multirow[t]{2}{*}{ Compound } & \multicolumn{2}{|c|}{ C (\%) } & \multicolumn{2}{|c|}{$\mathrm{H}(\%)$} & \multicolumn{2}{|l|}{$(\mathrm{H} \%)$} \\
\hline & Calc. & $\overline{\text { Found }}$ & Calc. & Found & Calc. & Found \\
\hline meso-3-PtI $\mathrm{I}_{2}$ & 24.3 & 24.1 & 2.33 & 2.42 & 4.0 & 3.9 \\
\hline meso-3-PtCl 2 & 33.0 & 32.9 & 3.16 & 3.31 & 5.5 & 5.4 \\
\hline DL-3-PtCl 2 & 33.0 & 33.0 & 3.16 & 3.24 & 5.5 & 5.0 \\
\hline
\end{tabular}


Table 2. ${ }^{1} \mathrm{H}-\mathrm{NMR}$ data of $\left[1,2\right.$-bis-(2-hydroxyphenyl)ethylenediamine]dihaloplatinum(II) complexes $\left(250 \mathrm{MHz}\right.$, dimethylformamide- $\left.\mathrm{d}_{7}\right)$ and of their ligands $\left(60 \mathrm{MHz}, \mathrm{CDCl}_{3} ; \mathrm{Me}_{3} \mathrm{Si}_{\text {int }}\right)$

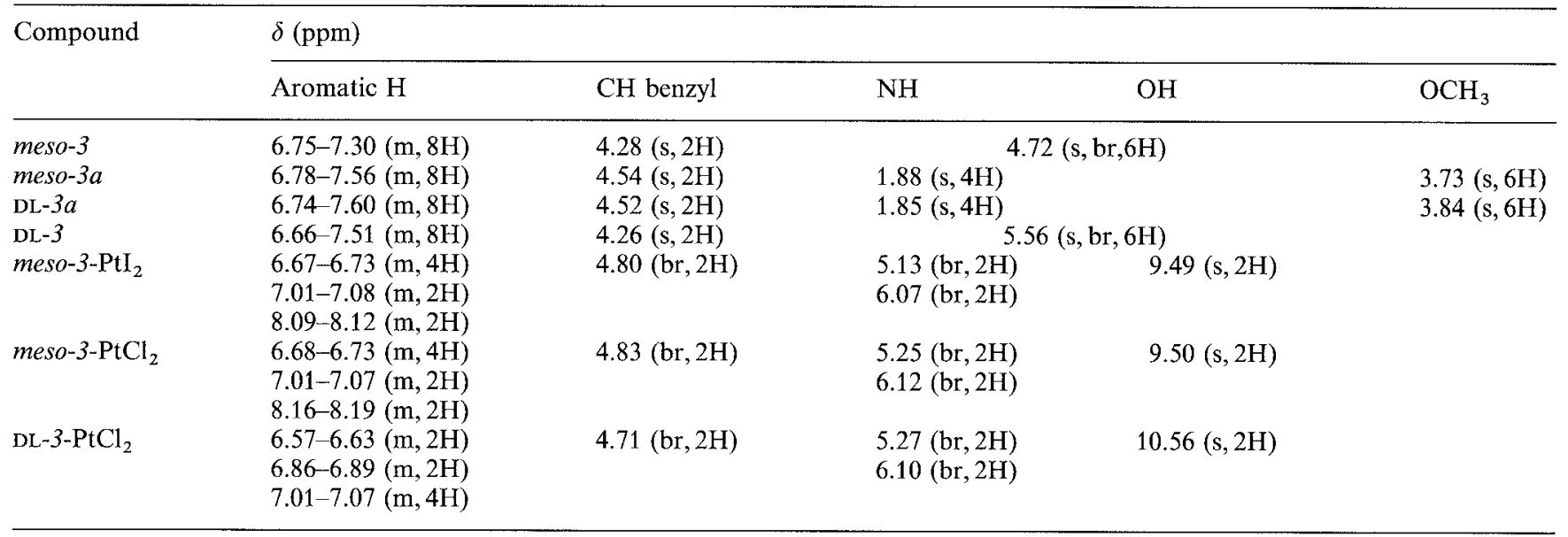

Table 3. ${ }^{1} \mathrm{H}$-NMR of $N, N^{\prime}$-dibenzylidene1,2-diphenylethylenediamines $\left(60 \mathrm{MHz}, \mathrm{CDCl}_{3} ; \mathrm{Me}_{3} \mathrm{Si}_{\text {int }}\right)$

\begin{tabular}{lllll}
\hline Compound & \multicolumn{1}{l}{$\delta(\mathrm{ppm})$} & & \\
\cline { 2 - 5 } & Aromatic $\mathrm{H}$ & $\mathrm{CH}$ benzyl & $\mathrm{N}=\mathrm{C}-\mathrm{H}$ & $\mathrm{OCH}_{3}$ \\
\hline meso-3c & $6.52-7.58(\mathrm{~m}, 16 \mathrm{H})$ & $5.45(\mathrm{~s}, 2 \mathrm{H})$ & $8.20(\mathrm{~s}, 2 \mathrm{H})$ & $3.61(\mathrm{~s}, 6 \mathrm{H})$ \\
meso-3b & $6.66-8.33(\mathrm{~m}, 16 \mathrm{H})$ & $5.44(\mathrm{~s}, 2 \mathrm{H})$ & $8.85(\mathrm{~s}, 2 \mathrm{H})$ & $3.64(\mathrm{~s}, 6 \mathrm{H})$ \\
& & & & $3.80(\mathrm{~s}, 6 \mathrm{H})$ \\
DL-3b & $6.54-8.29(\mathrm{~m}, 16 \mathrm{H})$ & $5.54(\mathrm{~s}, 2 \mathrm{H})$ & $8.84(\mathrm{~s}, 2 \mathrm{H})$ & $3.53(\mathrm{~s}, 6 \mathrm{H})$ \\
& & & & $3.64(\mathrm{~s}, 6 \mathrm{H})$
\end{tabular}

Table 4. HPLC analysis of the platinum complexes $3^{a}$

\begin{tabular}{ll}
\hline Compound & $t_{\mathbf{R}}(\mathrm{min})$ \\
\hline $\mathrm{DL}-3-\mathrm{PtCl} \mathrm{PL}_{2}$ & 4.8 \\
meso-3-PtI & 3.8 \\
meso-3-PtCl & 3.0 \\
\hline
\end{tabular}

a All compounds eluted as single peaks

in a $\mathrm{H}_{2} \mathrm{O}$-saturated atmosphere of $95 \%$ air and $5 \% \mathrm{CO}_{2}$. The cells were serially passaged weekly following trypsinization using tryp$\sin /$ EDTA (Boehringer).

For chemosensitivity testing the cells (in passage 30 ) were plated in 96-well microplates $(100 \mu \mathrm{l} /$ well $)$ at a density of about 19 cells/ microscopic field (Leitz Diavert, $320 \times$ ) and were allowed to attach. After $73.5 \mathrm{~h}$, the medium was removed by suction and replaced with fresh medium $(200 \mu \mathrm{l} /$ well) containing drug (drugs were added as a 1000 -fold stock solution in dimethylformamide) or pure solvent. On every plate the rows 5 and $6(n=16)$ acted as controls, whereas two vertical rows $(n=16)$ per drug concentration and time point were used. After varying times of incubation the cells were fixed with glutaraldehyde and stored under PBS at $4^{\circ} \mathrm{C}$. All plates were stained with crystal violet simultaneously. The processing procedure and data analysis were performed as described by Reile et al. (1989). Drug effects were calculated as corrected $T / C$ values according to: $T / C_{\text {corr }}=\left(T-C_{0}\right) /\left(C-C_{0}\right)$ where $T$ is the absorbance of treated cells, $C$ the absorbance of the controls and $C_{0}$ the absorbance at the time $(t=0)$ when drug was added. The experimental errors for $T / C_{\text {corr }}$ range from approximately $\pm 20 \%$ after short times of incubation (small values for $\Delta T$ and $\Delta C$ compared to $C_{0}$ ) to $\pm 5 \%$ with prolonged incubation.

L1210 leukemia cell line (a) (experiments concerning Fig. 7). The cytotoxicity of platinum compounds was determined by cloning cells of the L1210 murine leukemia or of its subline L1210/Pt (25-fold resistant) in soft agar. Treatments were for $1 \mathrm{~h}$ at $37^{\circ} \mathrm{C}$ in the presence of $10 \%$ fetal calf serum (Seromed, Biochrom company). Cells were not washed before cloning in soft agar since the medium was diluted $1: 400$ during this procedure. Cells were then plated in $30-\mathrm{mm}$ petri dishes (Falcon) and incubated for 7 days in $5 \% \mathrm{O}_{2}, 5 \% \mathrm{CO}_{2}$ and $90 \% \mathrm{~N}_{2}$. The final concentration of fetal calf serum was $20 \%$ in soft agar (Bacto Agar, Difco). Colonies ( $>50$ cells) were scored by inspection of petri dishes on an inverted Leitz microscope and fractional survival was plotted semilogarithmically. Cisplatin (Platinex, Bristol Myers company) was available as a stock solution in physiological saline and diluted appropriately with RPMI-1640 medium supplemented with $10 \%$ fetal calf serum. Compounds meso-3-PtCl and DL-3- $\mathrm{PtCl}_{2}$ were provided as crystalline white powders and were made up as stock solutions of $5.1 \mathrm{mg} / \mathrm{ml}$ with dimethylsulfoxide. Drug resistance to cisplatin was induced by intermittent exposures of $\mathrm{L} 1210$ cells to increments of $0.2 \mu \mathrm{g} / \mathrm{ml}$ of the drug in tissue culture if the cell doubling time during exposure and in the subsequent passage without drug was no more than 2-3 days. A total of 78 passages over 15 months were necessary to achieve the level of resistance found in the present experiment. During this time concentrations of cisplatin in the medium were increased from $0.1 \mu \mathrm{g} / \mathrm{ml}$ to $10 \mu \mathrm{g} / \mathrm{ml}$. L1210 leukemia cell line (b) (experiments concerning Table 7). Sensitive and resistant L1210 cells have been developed and described by Eastman and Illenye (1984) and by Richon et al. (1987). Suspension cultures are grown in McCoy's 5a (modified) medium supplemented with $\mathrm{NaHCO}_{3}(2.2 \mathrm{~g} / \mathrm{l})$, penicillin $(250 \mathrm{U} / \mathrm{ml})$, streptomycin $(250 \mathrm{U} / \mathrm{ml})$, fungizone $(1 \mu \mathrm{g} / \mathrm{ml})$ and $16 \%$ calf serum. For growth inhibition $4 \mathrm{ml}$ cell suspension (approximately $5 \times 10^{4}$ cells $/ \mathrm{ml}$ ) was incubated in triplicate with varying concentrations of drug over a 3day period. The drug was added as a 1000 -fold stock solution in dimethylformamide or dimethylsulfoxide. Stock solutions, especially dimethylsulfoxide solutions, were kept no longer than 5-10 min. After 3 days 1-ml aliquots were counted on a Coulter counter.

P388 leukemia. The P388 leukemia (Dawe and Potter 1957; Geran et al. 1972) was maintained by routine passage in female DBA/2 mice (Ivanovas, Kisslegg, FRG). For determination of antitumor activity, female $\mathrm{CDF}_{1}$ mice (18-22 g, Zentralinstitut für Versuchstiere, Hannover, FRG) were inoculated i.p. with $10^{6}$ leukemia cells in 
$0.1 \mathrm{ml}$ PBS buffer (day 0 ). The animals were assigned randomly to groups of six (ten animals to the solvent control) and the complexes were administered i.p. on days 1,5 , and 9 or $1-9$ as a solution in polyethylene glycol $400 / 1.8 \% \mathrm{NaCl}$ in $\mathrm{H}_{2} \mathrm{O}(1: 1)$. The antitumor activity was evaluated as the median survival time (days) compared to the untreated control.

Ehrlich ascites tumor. A hyperdiploid Ehrlich ascites tumor (ET $\left.\mathrm{ET}_{\mathrm{WT}}\right)$ was maintained by weekly transplantation of $2.5 \times 10^{7}$ tumor cells into female random-bred NMRI mice, as has been described earlier (Seeber et al. 1982). Tumor lines with documented in vivo resistance towards daunorubicin, doxorubicin, etoposide, cisplatin, 4-hydroxycyclophosphamide and also towards a combination of doxorubicin and cisplatin were developed by biweekly i.p. injections of increasing doses of the drugs as described (Seeber et al. 1982; Seeber 1982). In order to maintain a $>32$-fold anthracycline resistance, a $>8$-fold etoposide resistance and a $>4$-fold cisplatin resistance the tumor lines were intermittently exposed to the drugs in vivo using $5 \mathrm{mg} / \mathrm{kg}$ daunorubicin, $12 \mathrm{mg} / \mathrm{kg}$ etoposide and $8 \mathrm{mg} / \mathrm{kg}$ cisplatin at 2 - to 4-week intervals. For comparative analyses of the in vivo activities of cisplatin and the platinum complexes groups of ten animals were formed and $2.5 \times 10^{7}$ tumor cells were inoculated i.p. The drugs to be tested were injected i.p. $24 \mathrm{~h}$ later on days 1, 2, 3 as a solution in polyethylene glycol $400 / 1.8 \% \mathrm{NaCl}(1: 1)$. All animals were followed for survival for at least 30 days.

\section{Results and discussion}

The diastereoisomeric [1,2-bis(2-hydroxyphenyl)ethylenediamine]-dichloroplatinum(II) complexes DL-3-PtCl $\mathrm{Pl}_{2}$ and meso-3- $\mathrm{PtCl}_{2}$ were tested on the hormone-independent, human MDA-MB231 breast cancer cell line (Table 5). DL-3- $\mathrm{PtCl}_{2}$ shows a significantly stronger inhibitory effect on $\left[{ }^{3} \mathrm{H}\right]$ thymidine incorporation and cell growth than its diastereoisomer meso-3- $\mathrm{PtCl}_{2}$. The antitumor activity of $\mathrm{DL}-3-\mathrm{PtCl}_{2}$ is one-third that of cisplatin.

For testing the activity of DL-3-PtCl 2, meso-3- $\mathrm{PtCl}_{2}$ and cisplatin against ovarian cancer the NIH:OVCAR-3 cell line was used. Hamilton et al. (1983) have described this cell line to be resistant to clinically relevant concentrations of Adriamycin, melphalan and cisplatin.

In order to provide the most information, the data are presented as growth curves (absorbance plotted versus time of drug exposure) as well as correced $T / C$ values versus time of drug exposure. A gradual decrease of $T / C_{\text {corr }}$ values with time indicates an inhibition of cell growth (i.e. a slowing down or a stopping of cell proliferation $=\mathrm{cy}$ tostatic drug action). No change or increase of $T / C_{\text {corr }}$ values with time of drug exposure represents primary drug resistance or recovery of the cells from drug-induced damage, which may result in full reproductive integrity of

Table 5. Antitumor effect of $R, S$ and $R, R / S, S$ [1,2-bis(2-hydroxyphenyl)ethylenediamine]dichloroplatinum(II) on the hormoneindependent, human MDA-MB231 breast cancer cell line

\begin{tabular}{lllll}
\hline Compound & $\begin{array}{l}{\left[{ }^{3} \mathrm{H}\right]} \\
\text { Thymidine } \\
\text { inhibition } \\
\text { at } 5 \mu M \\
(\%)\end{array}$ & $\begin{array}{l}\text { Incorpo- } \\
\text { ration } \\
\mathrm{ED}_{50}\end{array}$ & $\begin{array}{l}\text { Inhibition } \\
\text { of cell } \\
\text { growth at } \\
5 \mu M\end{array}$ & $\mathrm{ED}_{50}$ \\
& $(\mu M)$ & $(\%)$ & $(\mu M)$ \\
\hline Cisplatin & 97.6 & 0.16 & 83.9 & 0.56 \\
$\begin{array}{l}\text { DL-3-PtCl } \\
\text { meso-3-PtCl }\end{array}$ & 95.3 & 0.60 & 85.7 & 1.5 \\
\hline
\end{tabular}

the cells (i.e. development of resistance) ${ }^{2} T / C_{\text {corr }}$ values $<0$ indicate cytocidal drug action.

Figure 1 shows the effect of cisplatin on the NIH:OVCAR-3 cell line. At the lowest concentration $(0.1 \mu \mathrm{M})$ the cells are weakly inhibited initially but fully recover after about $200 \mathrm{~h}$ drug exposure. This behavior can be explained by a resistance of the cell line against cisplatin, which is described by Hamilton et al. (1983). At higher (therapeutically non-relevant) concentrations clear-cut dose-dependent inhibition is observed. Compared to cisplatin for both DL-3- $\mathrm{PtCl}_{2}$ (Fig. 2) and meso-3- $\mathrm{PtCl}_{2}$ (Fig. 3) higher doses are required to achieve equiactive inhibition. Whereas DL-3-PtCl ${ }_{2}$ is cytocidal at $2.5 \mu \mathrm{M}$ and $5.0 \mu \mathrm{M}$, meso-3- $\mathrm{PtCl}_{2}$ exhibits a cytocidal effect only in its highest concentration $(5 \mu \mathrm{M})$. In contrast to DL-3$\mathrm{PtCl}_{2}$ the onset of action of meso-3- $\mathrm{PtCl}_{2}$ is delayed. $\mathrm{Al}-$ though the equiactive in vitro concentrations of the most active diastereoisomer $\mathrm{DL}-3-\mathrm{PtCl}_{2}$ are higher than those of cisplatin, there may be an advantage with this compound in the therapy of ovarian cancer owing to its markedly lower toxicity (i.e. the realization of cytocidal but non-toxic drug concentrations under in vivo conditions). ${ }^{3}$ Therefore, $\mathrm{DL}-3-\mathrm{PtCl}_{2}$ could be useful for the first-line treatment of ovarian cancer in combination with cisplatin to avoid development of resistance, as well as for the second-line therapy of the cisplatin-resistant tumor.

In the P388 leukemia experiments in vivo DL-3- $\mathrm{PtCl}_{2}$ proved to be very active (Table 6). In contrast, meso-3$\mathrm{PtCl}_{2}$ showed only marginal antitumor effects even at the highest tolerated dose. DL-3- $\mathrm{PtCl}_{2}$ is also much better tolerated than meso-3-PtCl 2 . DL-3-PtCl $2(30 \mu \mathrm{mol} / \mathrm{kg})$ has a better effect if it is applied in nine doses (days $1-9 ; T / C=$ $205 \%$ ) instead of three doses (days 1, 5, 9; T/C=170\%). The effect of DL-3- $\mathrm{PtCl}_{2}$ is comparable to that of cisplatin (dose: $3 \times 5 \mu \mathrm{mol} / \mathrm{kg}$, days $1,5,9 ; T / C: \mathrm{DL}-3-\mathrm{PtCl}_{2}=$ $170 \%$; cisplatin $=180 \%$ ). However, DL- $3-\mathrm{PtCl}_{2}$ is much less toxic than cisplatin. The dosage $9 \times 13.2 \mu \mathrm{mol} / \mathrm{kg}$ DL$3-\mathrm{PtCl}_{2}$ produced the strongest antitumor effect $(T / C=$ $300 \%$ ). At the end of the experiment (day 30 ) four out of six animals survived. After a further increase of dose, toxic side-effects became evident, which demanded a reduction of the number of doses from nine to five.

In further experiments the activities of meso-3- $\mathrm{PtCl}_{2}$ and DL-3-PtCl ${ }_{2}$ in wild-type $\left(\mathrm{ET}_{\mathrm{WT}}\right)$ and cisplatin-resistant $\left(\mathrm{ET}_{\mathrm{DDP}}\right)$. Ehrlich ascites tumor were studied. These results are demonstrated in Figs. 4 6. In the case of complex meso-3- $-\mathrm{PtCl}_{2}$ (Fig. 4) three daily doses of $5 \mathrm{mg} / \mathrm{kg}$ were curative and three of $10 \mathrm{mg} / \mathrm{kg}$ were already lethal

2 The development of resistance can also be feigned by the decomposition of the drug under the cell culture conditions used. This can happen particularly with highly reactive compounds like cisplatin, which exchanges its chlorine substituents for anionic components of the culture medium

3 The evaluation of $\mathrm{DL}-3-\mathrm{PtCl}_{2}$ on the P388 leukemia of the mouse proves that single doses of $40 \mu \mathrm{mol} / \mathrm{kg}$ are tolerated by the animals without complications (See also Table 6: animal weight change days 1-5). Therefore it is supposed that under in vivo conditions in ovarian cancer cytocidal DL-3-PtCl 2 levels $(\geqq 2.5 \mu \mathrm{mol} /$ $\mathrm{kg}$ ) are achievable. This is especially true for intraperitoneal and intrapleural administration. meso-3- $\mathrm{PtCl}_{2}$ is a less promising drug because of its lower antitumor activity and its higher toxicity (compare Table 6) 

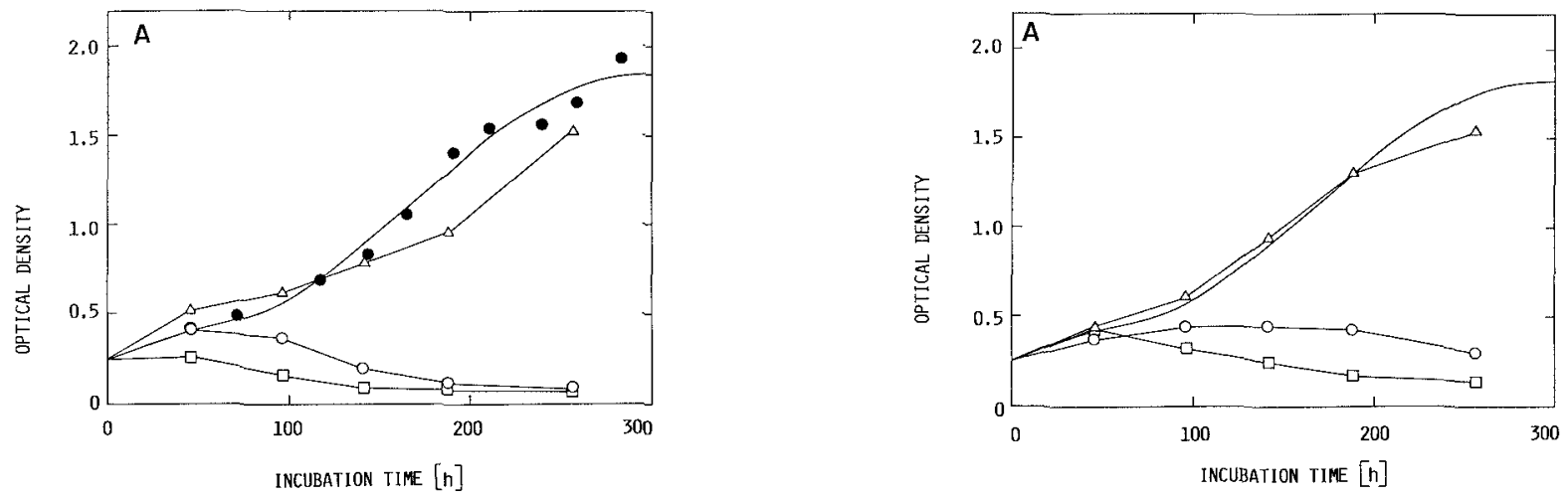

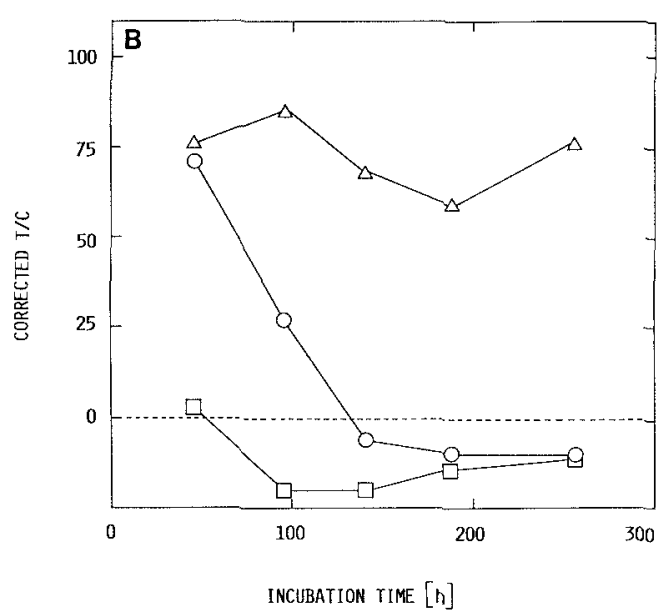

Fig. 1 A,B. Effect of cisplatin on the proliferation of NIH:OVCAR 3 ovarian cancer cells. A Growth curves. B Plot of corrected $T / C$ values versus time of drug exposure, where $T$ is absorbance of treated cells and $C$ is that of the controls. $\triangle, 0.1 \mu M ; O, 1 \mu M ; \square$, $5 \mu M ; \bullet$, absorbance of the dimethylformamide control with the curve fitted (Reile et al. 1989)

Table 6. Antitumor effect of $R, S$ and $\mathrm{R}, \mathrm{R} / \mathrm{S}, \mathrm{S}[1,2$-bis(2-hydroxyphenyl)ethylenediamine]dichloroplatinum(II) on the P388 leukemia of the $\mathrm{CD}_{2} \mathrm{~F}_{1}$ mouse

a The compounds were administered intraperitonally as polyethylene glycol $400 / 1.8 \%$ $\mathrm{NaCl}$ solution

b Three of ten animals survived the end of the test (day 30)

c Four of six animals survived the end of the test (day 30)

d Two of six animals survived the end of the test (day 30)

\begin{tabular}{|c|c|c|c|c|c|c|}
\hline \multirow[t]{3}{*}{ Compound } & \multirow{3}{*}{$\begin{array}{l}\text { Day } \\
\text { of } \\
\text { injection }\end{array}$} & \multicolumn{5}{|c|}{ Animal weight } \\
\hline & & \multicolumn{2}{|c|}{ Single dose ${ }^{a}$} & \multirow{2}{*}{$\begin{array}{l}\text { Change } \\
\text { days } \\
1-5\end{array}$} & \multirow{2}{*}{$\begin{array}{l}\text { Median survival } \\
\text { time (range) } \\
\text { (days) }\end{array}$} & \multirow{2}{*}{$\begin{array}{l}T / C \\
(\%)\end{array}$} \\
\hline & & $(\mu \mathrm{mol}$ & $(\mathrm{mg} / \mathrm{kg})$ & & & \\
\hline \multirow[t]{2}{*}{ Control } & $1,5,9$ & & & -1.8 & $10 \quad(10-12)$ & 100 \\
\hline & $1-9$ & & & -1.4 & $10 \quad(9-11)$ & 100 \\
\hline Cisplatin & $1,5,9$ & 5 & 1.5 & 1.4 & $18 \quad(16-21)$ & 180 \\
\hline \multirow[t]{6}{*}{ DL-3-PtCl 2} & $1,5,9$ & 40 & 20.4 & -0.4 & $22.5(17-25)$ & 225 \\
\hline & $1,5,9$ & 20 & 10.2 & -0.4 & $17 \quad(16-18)$ & 170 \\
\hline & $1,5,9$ & 10 & 5.1 & -1.0 & $17 \quad(17-19)$ & 170 \\
\hline & $1,5,9$ & 5 & 2.55 & -0.7 & $17 \quad(17-25)$ & 170 \\
\hline & $1-9$ & 3.3 & 1.68 & -2.1 & $20.5(17-25)$ & 205 \\
\hline & $1-9$ & 1.7 & 0.87 & 1.2 & $16(16-18)$ & 160 \\
\hline Control & $1-9$ & & & -0.5 & $(9-11)$ & 100 \\
\hline Cisplatin & $1-6$ & 3.3 & 1.0 & 3.4 & $(9-30)^{b}$ & 200 \\
\hline \multirow[t]{3}{*}{$\mathrm{DL}-3-\mathrm{PtCl}_{2}$} & $1-9$ & 6.6 & 3.4 & 0.0 & $21 \quad(20-25)$ & 210 \\
\hline & $1-9$ & 13.2 & 6.8 & 2.5 & $30 \quad(24-30)^{c}$ & 300 \\
\hline & $1-5$ & 26.4 & 12.6 & 4.4 & $28 \quad(8-30)^{\mathrm{d}}$ & 280 \\
\hline \multirow[t]{5}{*}{ meso-3- $\mathrm{PtCl}_{2}$} & $1,5,9$ & 40 & 20.4 & & Toxic & \\
\hline & $1,5,9$ & 20 & 10.2 & 4.0 & $13.5(6-16)$ & 135 \\
\hline & $1,5,9$ & 10 & 5.1 & -0.3 & $11(10-13)$ & 111 \\
\hline & $1-9$ & 6.6 & 3.37 & 0.4 & $14 \quad(10-14)$ & 140 \\
\hline & $1-9$ & 3.3 & 1.68 & 1.5 & $12.5(12-19)$ & 125 \\
\hline
\end{tabular}



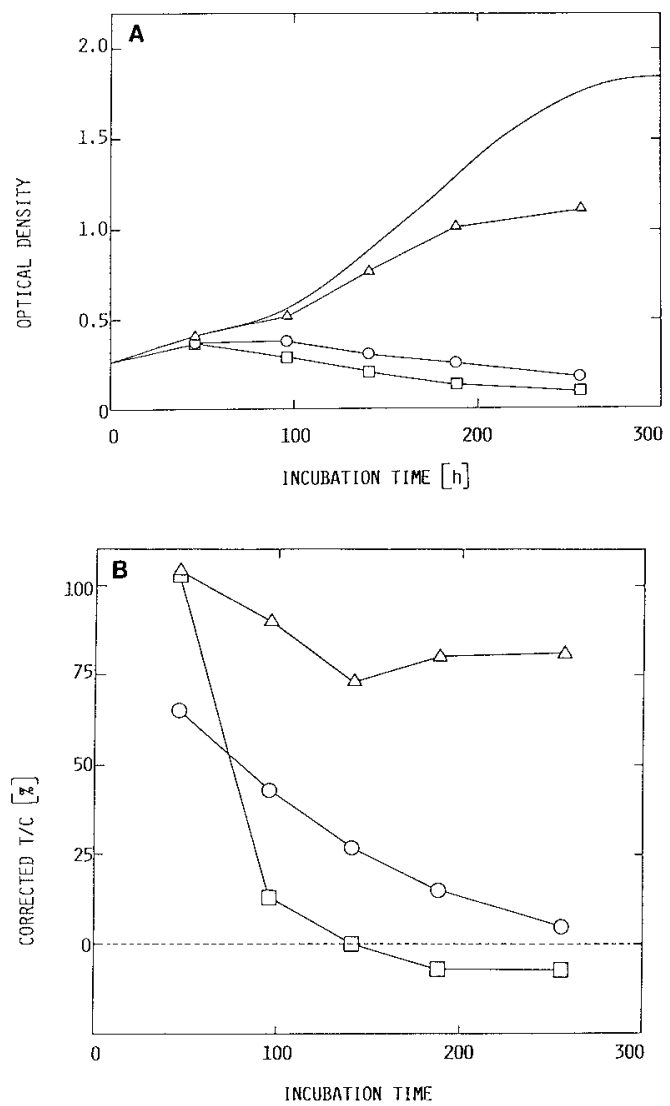

Fig. 3A, B. Effect of meso-3-PtCl 2 on NIH:OVCAR-3 cells. A Growth curves. B Corrected T/C values as a function of time of incubation. $\triangle 1 \mu M$; o $2.5 \mu M$; $\square 5 \mu M$; - computed control

in the wild-type tumor. For complex DL-3- $\mathrm{PtCl}_{2}$ the therapeutic ratio was improved in the wild-type tumor: as shown in Fig. 5 a dose range of $3 \times 5 \mathrm{mg} / \mathrm{kg}$ to $3 \times 10 \mathrm{mg} /$ $\mathrm{kg}$ was curative without any significant toxicity (compare also Table 6). The most important result of this study is demonstrated in Fig. 6. When both complexes meso-3$\mathrm{PtCl}_{2}$ and DL-3- $\mathrm{PtCl}_{2}$ were tested in the cisplatin-resistant subline in vivo, $70 \%$ of the tumor-bearing animals could be cured by complex DL-3- $\mathrm{PtCl}_{2}$ as compared to only $20 \%$ of the animals when treated with complex meso-3- $\mathrm{PtCl}_{2}$. This result was substantiated by a repeat experiment and is based on the documentation of in vivo activity in 20 animals altogether.

The lack of complete cross-resistance of DL-3-PtCl with cisplatin, found in the comparative testing on a cisplatin-sensitive and -resistant Ehrlich ascites tumor of the mouse, was also observed on the L1210 leukemia cell line. In these experiments, $\mathrm{DL}-3-\mathrm{PtCl}_{2}$ proved to be markedly more active than cisplatin on the cisplatin-sensitive L1210 cell line as well as on the cisplatin-resistant (25fold) $\mathrm{L} 1210$ subline (Fig. 7). meso-3- $\mathrm{PtCl}_{2}$ was comparably active with cisplatin on the sensitive L1210 cell line and inactive on the resistant L1210 subline (Fig. 7).

DL-3- $\mathrm{PtCl}_{2}$ was also tested against a series of resistant L1210 cell lines developed by Eastman et al. (1987). Only little cross-resistance was found against the L1210/DDP 5 and $\mathrm{L} 1210 / \mathrm{DDP}_{10}$ cells (DDP $=$ cisplatin), which are highly resistant against cisplatin (Table 7). It is of further

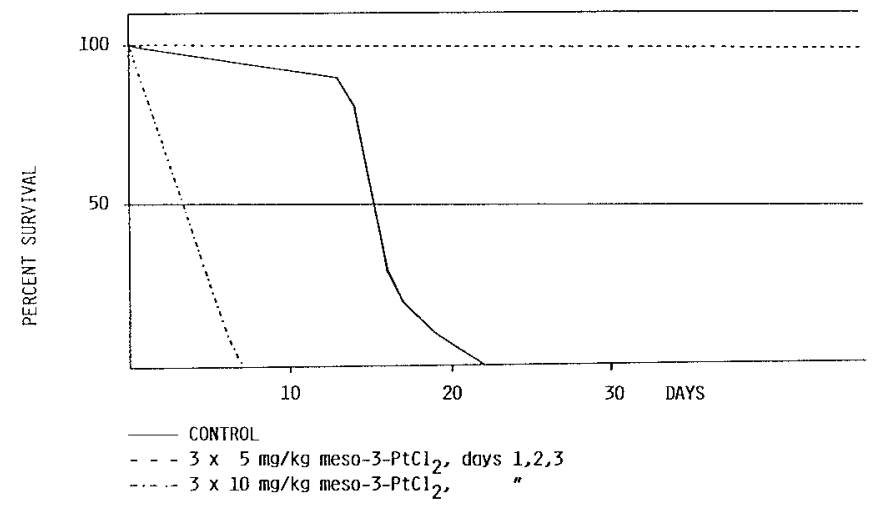

Fig. 4. Effect of the platinum complex meso-3-PtCl 2 on the cisplatinsensitive Ehrlich ascites tumor of the mouse

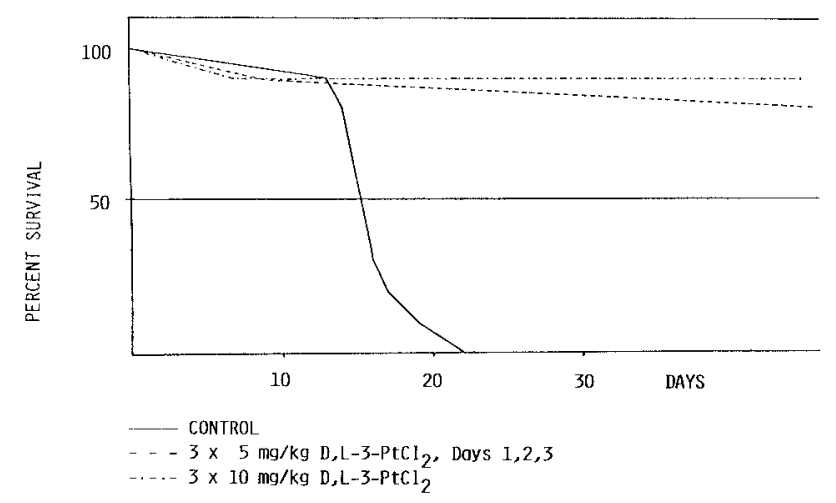

Fig. 5. Effect of the platinum complex DL-3-PtCl ${ }_{2}$ on the cisplatinsensitive Ehrlich ascites tumor of the mouse

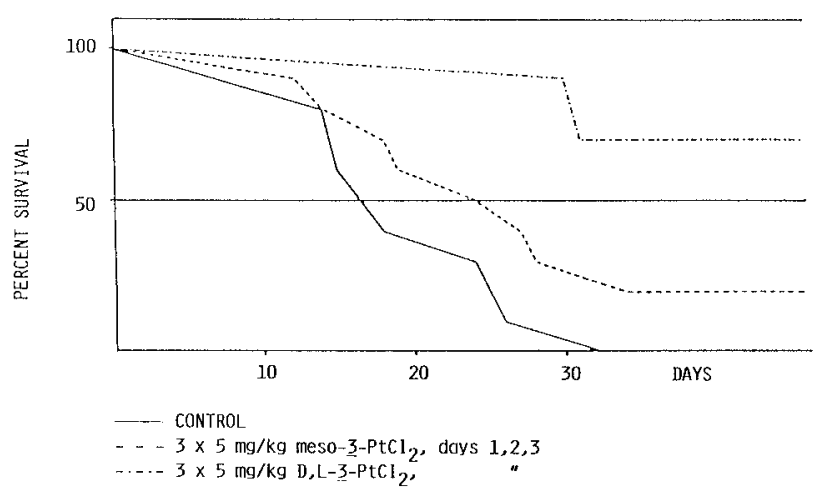

Fig. 6. Effect of the platinum complexes meso-3-PtCl 2 and DL-3$\mathrm{PtCl}_{2}$ on the cisplatin-resistant Ehrlich ascites tumor of the mouse

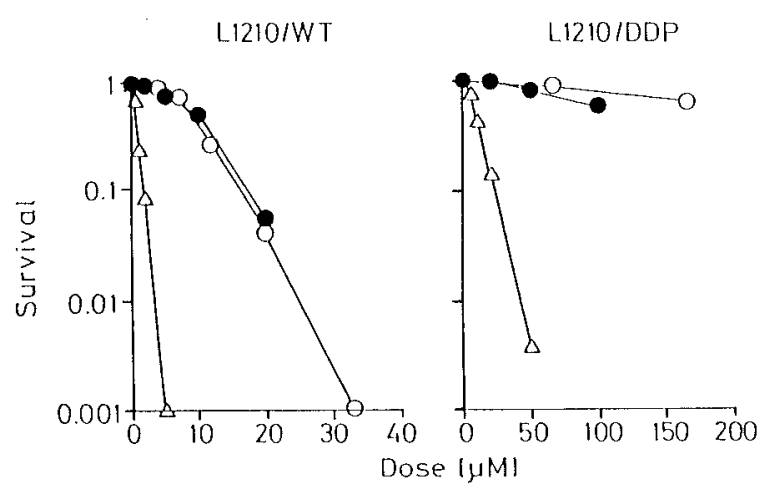

Fig. 7. Cytotoxic activity of cisplatin (DDP/O), meso-3-PtCl $\mathrm{Pl}_{2}(\bullet)$ and $\mathrm{DL}-3-\mathrm{PtCl}_{2}(\triangle)$ on the cisplatin-sensitive (L1210/WT) and on the cisplatin-resistant (L1210/DDP) L1210 leukemia cell line 
Table 7. Growth-inhibiting effect of DL[1,2-bis(2-hydroxyphenyl)ethylenediamine]dichloroplatinum(II) on various L1210 leukemia cell lines (numbers in paranthesis are-fold resistance)

\begin{tabular}{|c|c|c|c|c|}
\hline \multirow[t]{2}{*}{ Compound } & \multicolumn{4}{|c|}{$\mathrm{ED}_{50}(\mu M)$} \\
\hline & L1210/0 & $\mathrm{L}_{1210 / \mathrm{DDP}_{5}}$ & $\mathrm{~L}_{1210} / \mathrm{DDP}_{10}$ & $\mathrm{~L} 1210 / \mathrm{DACH}$ \\
\hline Cisplatin & 0.3 & $17(55)$ & $32(107)$ & $13(4)$ \\
\hline $\mathrm{DL}-3-\mathrm{PtCl}_{2}$ & 3.7 & $13(3)$ & $24 \quad(6)$ & $17(4.6)$ \\
\hline
\end{tabular}

interest that the L1210/DACH cells, which are 40-fold resistant to (1,2-diaminocyclohexane)dichloroplatinum(II) (DACH), also showed only marginal resistance to DL-3$\mathrm{PtCl}_{2}$.

Owing to its low toxicity ${ }^{3}$ and its antitumor effect on various models described here, $\mathrm{DL}-3-\mathrm{PtCl}_{2}$ is of great interest for further development. The effect on the NIH: OVCAR-3 ovarian cancer cell line makes this type of compound a promising candidate for use in the therapy of ovarian cancer. In further publications we will report on attempts to optimize DL-3-PtCl 2 .

Acknowledgements. The technical assistance of F. Birk, S. Dehen, B. Hofmann, P. Pistor and P. Richthammer is gratefully acknowledged. Thanks are also due to the Deutsche Forschungsgemeinschaft (SFB 234), the Matthias Lackas-Stiftung für Krebsforschung and the Fonds der Chemischen Industrie for financial support.

\section{References}

Barker GH (1983) Chemotherapy of gynaecological malignancies, Castle House, London

Barker GH, Pring DW (1981) Advances in the management of ovarian cancer. Update 123-133

Bruntsch U (1985) Sekundäre Chemotherapie beim fortgeschrittenen Ovarialkarzinom - neue Medikamente. Onkologie 8:410

Dawe CJ, Potter M (1957) Lymphocytic leukemia P 388 of the $\mathrm{DBA} / 2$ mouse. Am J Pathol 33:603

De Vita VT, Hellman S, Rosenberg SA (1982) Cancer - principles and practice of oncology. Lippincott, Philadelphia

Eastman A, Illenye S (1984) Murine leukemia L 1210 cell lines with different patterns of resistance to platinum coordination complexes. Cancer Treat Rep 68:1189

Eisenhauer EA, Swenerton KD, Sturgeon JFG, Fine S, O'Reilly SE (1986) Phase II study of carboplatin in patients with ovarian carcinoma: a National Cancer Institute of Canada clinical trials group study. Cancer Treat Rep 70:1195

Geran RT, Greenberg NH, Macdonald MM, Schumacher AH, Abbott B (1972) Protocols for screening chemical agents and natural products against animal tumors and other biological systems. J Cancer Chemother Rep 3:9

Hamilton TC, Young RC, McKoq WM, Grotzinger KR, Green JA, Chu EW, Whang-Peng J, Rogan AM, Green WR, Ozols RF (1983) Characterization of a human ovarian carcinoma cell line (NIH:OVCAR-3) with androgen and estrogen receptors. Cancer Res 43:5379-5389

Hay RJ (1988) The seed stock concept and quality control for cell lines. Anal Biochem 171:225-237

Japp FR, Hooker SC (1884) Chem Ber 17:2402
Jennerwein M, Gust R, Müller R, Schönenberger H, Engel J, Berger MR, Schmähl D, Seeber S, Osieka R, Atassi G, Maréchal-De Bock D (1989a) Tumor inhibiting properties of stereoisomeric [1,2-Bis (3-hydroxyphenyl) ethylenediamine] dichloroplatinum(II)-complexes. Part I: synthesis. Arch Pharm (Weinheim) $322: 25$

Jennerwein M, Gust R, Müller R, Schönenberger H, Engel J, Berger MR, Schmähl D, Seeber S, Osieka R, Atassi G, Maréchal-De Bock D (1989 b) Tumor inhibiting properties of stereoisomeric [1,2-bis (3-hydroxyphenyl) ethylenediamine] dichloroplatinum(II) complexes. Part II: biological properties. Arch Pharm (Weinheim) 322:67

Lai GM, Ozols RF, Smith JF, Young RC, Hamilton TC (1988) Enhanced DNA repair and resistance to cisplatin in human ovarian cancer. Biochem Pharmacol 37:4597

Lippman ME, Monaco ME, Bolan G (1977) Effects of estrone, estradiol, and estriol on hormone responsive human breast cancer in long-term tissue culture. Cancer Res 37:1901

Ozols RF, Young RC (1985) High-dose cisplatin therapy in ovarian cancer. Semin Oncol 12:21

Ozols RF, Behrens BC, Ostchega Y, Young RC (1985) High-dose cisplatin and high-dose carboplatin in refractory ovarian cancer. Cancer Treat Rev 12 [Suppl A]:59

Reile H, Birnböck H, Bernhardt G, Spruß T, Schönenberger $H$ (1990) Computerized determination of growth kinetic curves and doubling times from cells in microculture. Anal Biochem 186 (in press)

Richon VM, Schulte N, Eastman A (1987) Multiple mechanisms of cellular resistance to platinum coordination complexes. Cancer Res 47:2056

Seeber S (1982) Model studies of etoposide resistance. Cancer Treat Rev 9[Suppl A]:15-20

Seeber S, Schmidt CG, Nagel G, Achterrath W (1979) Cisplatin Derzeitiger Stand und neue Entwicklungen in der Chemotherapie maligner Neoplasien. Beiträge zur Onkologie Bd. 3, KargerVerlag

Seeber S, Osieka R, Schmidt CG, Achterrath W, Crooke ST (1982) In vivo resistance towards anthracyclines, etoposide and cisplatin. Cancer Res 42:4719-4725

Vögtle F, Goldschmitt E (1976) Chem Ber 109:1

Wappes B, Jennerwein M, von Angerer E, Schönenberger H, Engel J, Berger M, Wrobel KH (1984) Dichloro[1,2-bis(4-hydroxyphenyl)ethylenediamine]platinum(II) complexes: an approach to develop compounds with a specific effect on the hormone-dependent mammary carcinoma. J Med Chem 27:1280

Weiss CR (1986) Second-line chemotherapy for ovarian cancer. Clin Obstet Gynecol 29:665

Wiltshaw E, Carr B (1974) Cisplatinum II diamminedichloride: clinical experience of the Royal Marsden Hospital and Institute of Cancer Research (London). Rec Results Cancer Res 48:178

Wiltshaw E, Kroner T (1976) Phase II study of cis-dichlorodiammine platinum(II) in advanced adenocarcinoma of the ovary. Cancer Treat Rep 60:55 